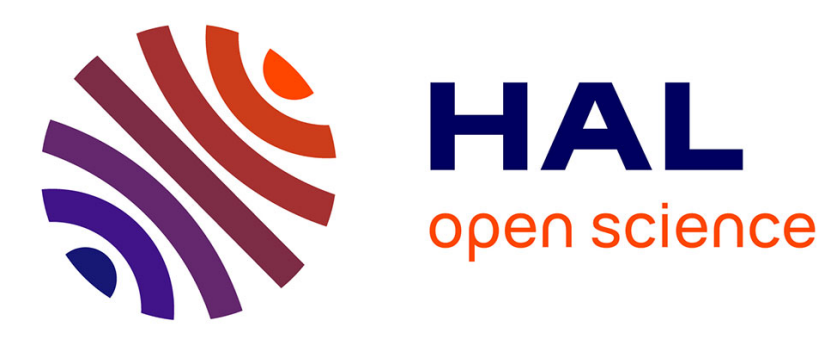

\title{
State, market or community failure? Untangling the determinants of groundwater depletion in Copiapó (Chile)
}

Jean-Daniel Rinaudo, Guillermo Donoso

\section{To cite this version:}

Jean-Daniel Rinaudo, Guillermo Donoso. State, market or community failure? Untangling the determinants of groundwater depletion in Copiapó (Chile). International Journal of Water Resources Development, 2019, 35 (2), pp.283-304. 10.1080/07900627.2017.1417116 . hal-02532239

\section{HAL Id: hal-02532239 \\ https://hal.science/hal-02532239}

Submitted on 4 Apr 2020

HAL is a multi-disciplinary open access archive for the deposit and dissemination of scientific research documents, whether they are published or not. The documents may come from teaching and research institutions in France or abroad, or from public or private research centers.
L'archive ouverte pluridisciplinaire HAL, est destinée au dépôt et à la diffusion de documents scientifiques de niveau recherche, publiés ou non, émanant des établissements d'enseignement et de recherche français ou étrangers, des laboratoires publics ou privés. 


\title{
State, market or community failure? Untangling the determinants of groundwater depletion in Copiapó (Chile)
}

\author{
Rinaudo, J. D., \& Donoso, G
}

This paper analyses the factors that explain why groundwater can be overexploited despite the existence of sophisticated water laws, institutions and effective state agencies responsible for water management. The analysis is based on a case study conducted in the Copiapó Valley in Northern Chile. Based on an analysis of water use data, policy documents and interviews with a variety of stakeholders, the paper highlights the state's failure to perform some of its key missions and the ineffectiveness of groundwater users' associations in water management despite a very supportive legal framework. The paper concludes with some recommendations on how ensure long-term sustainable groundwater use.

Keywords: Chile; collective management; governance; groundwater depletion; water policy

\section{Introduction}

Since the 1980s, irrigated agriculture has significantly expanded with the increasing use of groundwater. This trend, observed both in developed and emerging countries, has given rise to many cases of groundwater overdraft (Giordano \& Villholth, 2007; Mays 2013; Shah 2005; Wada et al., 2010). In certain cases, this has led groundwater dependent economies to the verge of collapse (Petit et al., 2017). Examples of such trajectories have been reported from settings as diverse as Australia (Nevill, 2009), southern European countries (De Stefano, Fornés, López-Geta, \& Villarroya, 2015), West American states (Scanlon et al., 2012), Central and South America (Bitran, Rivera, \& Villena, 2014; Scott \& Shah 2004), the Indian subcontinent (Wato \& Mugera, 2016), the Middle East (Al-Sakkaf et al., 1999) and North Africa (Kuper et al., 2016). 
This threat is a matter of increasing concern to states that have invested in agricultural development policies via subsidies and infrastructure development. Indeed, they now realize that groundwater overdraft could render their investments worthless and create poverty in regions where there was once economic expansion (Faysse, Errahj, Imache, Kemmoun, \& Labbaci, 2014). Policy makers are increasingly aware of the urgent need for policies that are designed to ensure that groundwater exploitation is sustainable in the long term (McKay, 2012). In this regard, a number of international experts and institutions recommend adjusting the existing groundwater allocation regimes by tightening the conditions for the allocation of water licenses, decreasing total abstraction and aligning it with available resources in the long-run. This management model, which is also applied to other natural resources, such as fisheries, assigns a major role to the state. It assumes that the state has the capacity to perform five tasks. The first consists of calculating and imposing a Sustainable Abstraction Limit (SAL), which is designed to guarantee the continuity of use for future generations (offtake should not exceed the long-term recharge) and to ensure that groundwater dependent ecosystems, such as streams and wetlands, fulfil their ecological function properly. The second task consists of sharing the resource concerned by the Sustainable Abstraction Limit among the various users. This can take the form of individual use rights (permits, concessions or full property rights), which define the terms of use by volume or discharge, the location and, possibly, the type of use associated with the withdrawal. Various principles of efficiency or social justice may underlie this initial allocation (Rinaudo, Moreau, \& Garin, 2016). Mechanisms enabling the reallocation of rights among users should also be laid down by the state (Task 3). The latter may make use of administrative procedures (waiting list), the market (if water use rights are made 
tradable) or other negotiated rules defined by the users themselves (decentralized management). The purpose is to adapt the initial allocation of rights to the changing economic or demographic conditions or to the exit or entry of users, with the primary objective of achieving economic efficiency. Finally, the state should set out the rules to be applied when it comes to adjusting the volume of rights granted (Task 4) in the event of a reduction in the available resource (across the board reduction of all rights, or expropriation with compensation), by considering the trade-off between efficiency and equity (Iftekhar \& Fogarty, 2017). This management model only works if users comply with the limits set for the rights of use. More generally, an efficient enforcement strategy is required to ensure that the users abide by the rules (Task 5).

This policy model based on the allocation of WR has gradually been implemented in developed countries where public administrations have the human, technical and financial resources to carry out the tasks described above. Australia (Grafton, Horne, \& Wheeler, 2016), Spain (De Stefano et al., 2015) and Chile (Bauer 2004; Donoso, Melo, \& Jordan, 2014a) are frequently cited to illustrate this model. European countries are now working on setting up a similar model, in line with the Water Framework Directive (EC, 2000). This raises several questions. What is the reality of the situation? Have all the requisite conditions for the successful operation of this type of management been met? This policy model assumes that the state will carry out its sovereign duties unfailingly and implement the five tasks described above. This article demonstrates that this is easier said than done, even in countries with a long water management tradition, sophisticated water laws and well-organized state agencies responsible for water management. This paper investigates the issue through the 
historical analysis of the Copiapó Valley, which is located in an arid region of northern Chile.

The article begins by presenting the regulatory framework for water management in Chile. It then describes the history of the case study and the resulting overdraft situation. In the fourth section, we then attempt to identify all the causal factors behind the overdraft between 1985 and 2010. The analysis reveals a number of state failures. The fifth section lays out the new approach that has been implemented during the past decade, based on the creation of user associations. The example of one of the associations, established in 2005 , is described in detail before presenting the challenges that it will face in the coming years. The article concludes with a discussion on the difficulty of balancing the roles of the state, collective management and market mechanisms when it comes to establishing long-term sustainable groundwater management.

\section{The regulatory framework for water management in Chile}

Defining and applying users' water rights (WR) is a basic element of water management in Chile (Bauer, 2004; Donoso, 2015). Since the colonial period, WR have largely involved sharing out the water distributed by collective hydraulic infrastructure systems (Vergara, Arévalo, Muñoz, Rivera, \& Vergara, 2011; Vergara, 1992). This is the case in a number of countries in North Africa, the Middle East and the Indian sub-continent (Giordano \& Villholth 2007). In the 1980s and 1990s, given the allocation and use of most surface water resources, there was an increase in groundwater withdrawals.

However, the Chilean Water Code of 1981 (WC81) (Gobierno de Chile, 1981) was designed essentially to regulate surface water. Consequently, it barely mentions 
groundwater (Rivera, 2015). In response to the need to regulate groundwater exploration and pumping and provide a legal framework and technical instruments to achieve sustainable groundwater management, the General Directorate of Water (DGA) promulgated Resolution 207-1983, which was revised in Decree 203-2013 (Gobierno de Chile, 2013). This applied the same system of rights to groundwater management: the water resource was seen as a national good for public use and the state granted withdrawal authorizations on request, free of charge. Authorizations were specified in terms of flow (not volume), as was traditionally the case in hydraulic systems; since 2005, authorizations specify both a maximum instantaneous pumping flow and an annual volume. While water resources remained in the public domain, under the neoliberal ideology of the ruling elite (Milton Friedman's Chicago Boys), the deed giving the right to use them was considered as a private good, with the same level of guarantee as land ownership (Bauer, 2004). Thus, WR were administered according to the same principles as real estate.

The WC81 stipulates that the state will cease awarding new rights if users can demonstrate (before a court) that their rights are threatened by newcomers. In addition, the state can close access to aquifers by declaring them prohibition zones. It can also declare restriction zones where only provisional WR can be allocated if there is uncertainty with regard to the available groundwater resources. The law also provides for an overdraft situation, which involves the uniform reduction of the flow associated with each water use right in order to re-establish a hydrogeological balanced situation.

Users are required to monitor their usage and send the data to the relevant waterpolicing office (Directorate General for Water - DGA). In restriction and prohibition zones, users are also required to form groundwater user associations (GWAs), which are 
in charge of ensuring that users comply with their rights. The DGA can legally cancel WR and expropriate users (with compensation), if it is justifiable in terms of the public interest with regard to protecting the environment or third parties. However, this has not yet been applied since the promulgation of the WC81 (Donoso \& Vicuña, 2016). There are two main reasons that explain this. In first place, the cost of expropriation is burdensome for the government, especially in arid and semi-arid basins where the value of WR is very high on average; in the northern arid regions, the value fluctuates between USD 130,000/1/s (Cristi, Melo, \& Donoso, 2014) and USD500,000/1/s (EMG, 2011). In second place, its application would lead to an important social and political conflict, due to the transfer of wealth to the WR holder who received them free of charge.

Therefore, the legislative and regulatory framework seems to be perfectly adapted for implementing the management model described in the introduction to this article. Let us now consider the current situation in the Copiapó Valley to determine whether what happens in practice actually corresponds to the theory.

\section{The groundwater crisis in the Copiapó Valley}

\section{Copiapó, an economic boom in the middle of the desert}

The Copiapó Valley is located in the Atacama district, in the semi-desert region of northern Chile (Figure 1). The watershed covers an area of 18,000 km2, extending from the Andean summits to the ocean over a distance of $160 \mathrm{~km}$. The groundwater resource is located in the valley bottom. It ranges from 1 to $5 \mathrm{~km}$ wide and constitutes a major quaternary alluvial aquifer. It is $100 \mathrm{~m}$ thick on average and divided into six large sectors (Figure 1). Some sub-sectors have greater reserves because the alluvial 
formation is thicker, with a depth of up to 200 metres (Figure 2). The resource is largely derived from melting snow and ice in the Andes and, to a lesser extent, from precipitation, which ranges between 20 and 50 mm per year in the Copiapó Valley. Average surface water flows are $2.4 \mathrm{~m} 3 / \mathrm{s}$. Flow is regulated by the Lautaro Reservoir, located at the head of the river, which has an intra-annual water regulation capacity of 25.4 million $\mathrm{m} 3$. This reservoir is one of the aquifer's major recharge sources.

[Insert Figure 1]

[Insert Figure 2]

Since 1990, mining activities have intensified with the arrival of major foreign investors, who have opened very high capacity copper mines, mainly located in Sector 4 (Sernageomin, 2017). Mining companies have been granted new rights from the state and they purchased others to farmers who owned more WR than they actually required for their own operations (Donoso, Blanco, Vergara, \& Rivera, 2014b).

Agriculture has also developed since the construction of the Lautaro dam in the 1930s, which provided a regular supply of water via a network of existing gravity-fed canals. The liberal policy adopted in the 1980s boosted the growth of intensive exportbased agricultural production (Oyarzún, Arumí, Alvarez, \& Rivera, 2008). At the time, the Copiapó Basin specialized in the production of table grapes, which were the first to reach the US market during the Christmas season. This period saw the development of large firms in the valley, managed by big landowners or held by foreign investors. As a result of the land reforms in the 1960s, peasant farmers coexisted alongside this capitalintensive agriculture. They specialized in truck farming for regional and national markets. Olive growing was also developed downstream, generally on a large scale, where the water is of less good quality. The state supported these developments mainly 
via policies to promote exports and, to a lesser extent, by providing subsidies for modernizing irrigation (drip irrigation, canal lining and by shifting from gravity to pressurized irrigation systems). The public policy set out to encourage competition, without providing direct support to companies.

Cultivated areas expanded from 3,400 ha in the 1960 s to 7,000 ha in the 1990 s and to 15,000 ha in 2015 . Fruit production represents $87 \%$ of the cultivated area; $79 \%$ of the irrigated land for fruit is used for table grape production and $17 \%$ for olives (Partarrieu et al., 2009). Surface irrigation systems were modernized (with widespread use of drip irrigation and cementing of the canals), which made it possible to increase production using the same amount of water. At present, drip or microjet technologies are employed on approximately $88 \%$ of the total irrigated area (Partarrieu, et al., 2009). However, agricultural development was also permitted by an increase in groundwater withdrawals, which rose from 10 million $\mathrm{m} 3$ in the 1960 s to more than 140 million m3 in the mid-1990s. It is important to note that 10 years ago, it was estimated that $78 \%$ of all recharge to the aquifer came from the riverbed and irrigation canals, with a further 17\% from drainage below the irrigated crops (Golder Associates, 2006). In recent years, the very high water use efficiency of drip irrigation systems, combined with the low river flows since 1998, has reduced recharge to the aquifer.

The combination of economic and demographic growth, which accompanied the mining and agricultural boom, also led to one of the highest population growth rates in the country (INE, 2012). This trend is expected to continue, given that the state has approved foreign investment in new and expanding mining projects (COCHILCO, 2013). Thus, there has also been a significant rise in drinking water demands, which also was met from groundwater (ECONSSA, 2014). The private company which 
manages drinking water supply (under a concession arrangement), has also obtained WR from the state and bought others to farmers (Donoso, et al., 2014b, ECONSSA, 2014). By the end of the 2000s, agricultural use accounted for $75 \%$ of groundwater withdrawals, while mining and industrial activities accounted for $15 \%$ and drinking water supply 10\%. (Donoso, et al., 2014b)

\section{Collapse of the water table}

Since the 1980s, a number of studies (e.g. Hammer \& Associates, 1980; Alamos \& Peralta, 1987; Dictuc, 2010; Troncoso et al., 2012; Hidromás CEF limitada, 2013) have shown that withdrawals far exceed the average recharge of the alluvial aquifer, estimated at $4 \mathrm{~m} 3$ per second (Troncoso et al., 2012). This is confirmed by the rapid fall in piezometric levels, which first appeared during the 1990s (the 1980s recorded above average rainfall). In the upstream sectors 1 and 2, the local groundwater balance is not critical and the aquifer recovers every year, as supplies from melting snow more than compensate for pumping. The deficit is growing in sectors 3 and 4 and the levels measured fell from 10 to 150 metres (on average) between 1998 and 2015. This is the area with the greatest concentration of high capacity pumping wells, which are mainly used for drinking water and mining purposes. Initially, Sectors 5 and 6 were spared because they benefited from recharge from lateral basins. Overall, the hydrogeological balance has been increasingly negative since the late 1990s (Figure 3): the total available water reserve fell by about 38 million m3 per year between 1990 and 2012 . The shortfall then accelerated sharply between 2005 and 2012 to 55 million m3 per year (Hidromás CEF limitada, 2013). In this 22-year period, the reserve lost an estimated 830 million $\mathrm{m} 3$, the equivalent of 6.5 years of average recharge. Figure 4 shows that the 
water reserve will continue to decline if the rate of groundwater pumping remains at its current level (McFarlane \& Norgate, 2012), unless average rainfall increases to the amounts recorded in the 1980s.

\section{[Insert Figure 3]}

\section{[Insert Figure 4]}

In Sectors 3 and 4, given the lower well productivity and the risk of wells drying up, the mining companies began purchasing groundwater rights from farmers in Sector 5 (McFarlane, Trefry, Moffat, \& Lacey, 2012). This appropriation, while perfectly legal, generated widespread hostility towards the mining sector within the agricultural community. For example, farmers expressed concern about the fact that the mining companies could afford to pay higher prices for WR than the farmers themselves; in fact, when a WR transaction was between a mining company and an agricultural producer, the price was, on average, $48 \%$ higher than a WR transaction only between farmers (Donoso et al. 2014b). They feared that this would be detrimental to regional agricultural activities (Red Agrícola, 2016). This, combined with the 2007 water shortage, led the major mining firms to invest in desalination plants and reduce groundwater use; mining companies reduced their water extraction in $238 \mathrm{l} / \mathrm{s}(-14 \%)$ between 2009 and 2013, while increasing their desalinated water consumption in 248 1/s in the same period (COCHILCO, 2013). In 2013, the boreholes at the Candelaria Mine were replaced by desalinated water, transported over a distance of $80 \mathrm{~km}$ to an elevation of $1,000 \mathrm{~m}$, at a total cost of about USD $4 / \mathrm{m}^{3}$. A second large mining firm (CAP) adopted the same strategy in 2014. The groundwater boreholes and the corresponding water use rights were kept as an emergency back-up supply. However, the reduction in 
withdrawals was not enough to curb the continuing fall in the piezometric levels. This reflects the fact that agriculture is the principal water user.

The company Aguas Chañar, which operates the drinking water service concession, now finds itself in the same situation. Their total extractions flows in sector 4 fell significantly (Figure 5) as Table 1 indicates the majority of its wells in Sector 4 yielded only a small volume of water because of the fall in the piezometric level (ECONSSA, 2014, 2015). So far, there is no indication of a reversal of this trend (Figure 4). Under an emergency procedure the DGA authorized Aguas Chañar to drill new wells in Sector 5 to replace the dry wells in Sector 4 (Donoso \& Vicuña, 2016). The new wells, with a total capacity of $540 \mathrm{~L} / \mathrm{s}$, were regularized by purchasing or leasing rights from farmers. In turn, the increase in the volumes drawn has led to a fall in the piezometric level in Sector 5 at a rate of approximately 2 to $6 \mathrm{~m}$ per year, depending on the location. According to the firm's technical manager, this sector of the aquifer is being emptied 'like a flush toilet' (Barros, personal communication, April 8, 2015).

\section{[Insert Table 1]}

\section{[Insert Figure 5]}

Aguas Chañar, thus, proposed the construction of a seawater desalination plant to replace the groundwater supply. However, despite the regional public subsidies to help finance the investment, operational costs would significantly increase household's potable water bill. Some estimates suggest that bills would double, making water unaffordable for some domestic users (ECONSSA, 2014). The project is at the environmental impact assessment stage, and it is projected that its initial phase will be operational in 2020 . 
A census conducted by the authors shows that an increasing number of boreholes for agricultural use are also drying up. In some cases, replacement wells have been constructed and the water use rights have been transferred from the initial wells to replacement wells. However, a number of WR attached to dry wells remain unused. In Sectors 5 and 6, we identified 42 wells which are currently dry (see Table 2). These wells could be replaced by deeper ones (average depth of 140 metres compared to 65 metres for the dry wells) with an estimated total cost of 2.65 million euros (Table 2). The deep semi-confined layers of the aquifer, which are currently being tapped, are poorly replenished and, therefore, the new wells are not very productive. Some farmers who drilled wells that are 110 m deep have watched their new well dry up in less than 2 years since it became operational. We are witnessing the first bankruptcies among agricultural firms. This crash is only partially cushioned by the sale of WR because the water market plummeted in 2008 .

\section{[Insert Table 2]}

So far, there is no indication to suggest any reversal of this trend. For example, a new mining company (Caserones) will soon commence operations upstream of the basin (Sector 1). It is likely to make intensive use of the WR purchased from farmers, which the latter were not using (equivalent to $1,095 \mathrm{~L} / \mathrm{s}$ ). According to their environmental impact assessment, certain areas of Sectors 3, 4 and 5 will probably dry up in the near future (Minera Lumina Copper Chile, 2008).

\section{The origins of the crisis}

How did this level of over-exploitation occur when the state theoretically has the regulatory tools to avoid this kind of situation? Was sufficient information available 
with regard to the status of the aquifer? If so, why did the state continue granting new permits? Is the state capable of determining the amounts of water that are actually being drawn off? To answer these questions, we reviewed 12 studies on the Copiapó aquifer (Alamos \& Peralta, 1987; Bitran et al., 2014; Dictuc, 2010; Donoso et al., 2014b; Golder Associates, 2006; Hammer \& Asociados, 1980), Hidromás CEF limitada, 2013; McFarlane \& Norgate, 2012; McFarlane et al., 2012; Minera Luminar Copper Chile, 2008; Partarrieu et al., 2009; Troncoso R et al., 2012) which were conducted in the last 25 years. We also used primary data, such as the WR registry and market trading data (the data can be requested from CASUB). In addition, we conducted a series of semistructured interviews with key stakeholders and experts, including farmers, members of GWAs and government agencies. We used a predominantly qualitative approach to outline the factual developments in Copiapó's groundwater management. Interviewees were selected on the basis of their involvement in water management activities and expertise.

\section{Limited knowledge of groundwater}

The basin has been the subject of a number of major studies, which have alerted the authorities to the danger of over-exploitation (Alamos \& Peralta, 1987; Dictuc, 2010; Hidromás CEF limitada, 2013; Troncoso et al., 2012). However, these successive studies conveyed different messages as to the consequences of over-exploitation. The first study (Hammer \& Asociados 1980) estimated the extracted volume to be 23-25 million $\mathrm{m} 3$. The authors also found that usage already exceeded recharge by $18 \%$, which diminished the groundwater reserve by 59 million m3 between 1970 and 1979 . This conclusion was contradicted by the study by Alamos and Peralta (1987), which 
stated that 'the Copiapó Valley has a vast underground reservoir with a capacity for regulation, and that it can be exploited for the next 50 years, including during droughts, without a significant fall in piezometric levels'. This optimistic conclusion was influenced by a series of wet years, which affected the hydrological statistics, and by the failure to anticipate the dramatic increase in demand for groundwater that was to occur in the following decades. In the wake of this study, users seeking to expand their economic activity could argue in court against the administration, if the latter refused to grant them new permits, since prior to the 2005 WC81 reform, the DGA could not refuse to grant new WR without infringing a constitutional guarantee, provided there was technical evidence of the availability of water resources and that the new use would not harm existing rights holders. At the time, the central government was investigating the issues surrounding the opening of several major mines. On the basis of the report, it argued in favour of the projects with the potential to generate growth and substantial tax revenues. Thus, the lack of reliable technical information on the characteristics of the Copiapó aquifer - recharge and sustainable yields - is one of the factors that led to over-allocation and the late establishment of abstraction limits.

\section{Legal complexity and political pressure}

When the fall in the piezometric levels in sectors 3 and 4 was acknowledged, the DGA finally classified the Copiapó Basin as a prohibition area in 1993 (Resolución 193; Gobierno de Chile, 1993); the DGA can declare an aquifer or the hydrogeological sector of an aquifer under prohibition if there is clear evidence of a risk of resource depletion due to over-extraction and at least one WR holder requests it. Thus, no new pumping permits could be granted. However, in 1994, DGA passed Resolución 232 (Gobierno de 
Chile, 1994), which lifted the prohibition in areas located more than $35 \mathrm{~km}$ from the river. As a result, a number of mining projects were revived after being granted new WR. However, this reduced groundwater recharge (DICTUC, 2010). More surprising still, numerous permits were granted after the prohibition had been declared (Figure 6). In fact, the total authorized pumping flow rose from about 14,500 L/s in 1993 to 18,500 $\mathrm{L} / \mathrm{s}$ in 2001 , an increase of nearly $30 \%$. Why did the state continue to issue permits? Firstly, users who had submitted their permit applications before the publication of the prohibition went to court and obtained a legal decision requiring the state to process their applications. In addition, many users anticipated the prohibition and requested the regularization of their customary WR (historic usages), according to the transitory second article of the WC81. The state controller ruled that the DGA was obliged to process these petitions under the prohibition. A few applications to regularize were old wells submitted to the DGA on the basis of false declarations (age of boreholes). This was also reported in the Ligua Petorca Basin by a different author (Budds, 2009). Finally, a number of accounts suggest that the local authority may have been under pressure from influential users, who had relations in the central government and in Santiago's political circles. By 2012, the DGA had granted water pumping rights allowing a total extraction of $20,000 \mathrm{~L} / \mathrm{s}$, five times the average recharge rate (Donoso et al., 2014b).

\section{[Insert Figure 6]}

In 2001, with the agreement of the National Agricultural Development Agency of the Ministry of Agriculture (INDAP), the DGA passed Resolución 232 (Gobierno de Chile, 1994), which lifted the prohibition for the downstream portion of the basin and classified it as a restricted zone. This status allowed provisional permits to be granted 
and regularized after 5 years, if no negative impact was demonstrated. Accordingly, new permits were distributed, particularly, though not exclusively, to small farmers (a widely-publicized social goal). As a result, mining companies were able to move from sectors 3 and 4, which were drying up, to sector 5 where the largest reserves were located. Did this decision reflect state arbitrage in terms of its dual objectives of economic growth and sustainability? Does it reflect the influence of big companies in the mining sector? These theories are difficult to prove.

\section{Ill-defined water permits}

Granting rights on the basis of a foreseeable use factor is a third technical issue, which could also account for the over-exploitation. During the 1990-2000 period, the DGA estimated the number of permits that could be granted to beneficiaries by taking into account their intended use. Thus, a water permit of 1 litre per second theoretically gives the right to pump 31,500 m3/year, if the permit is used 24 hours a day, 365 days a year. Since agricultural producers only pump water between late spring and the end of summer, the DGA assumed that there would be a $20 \%$ use factor. In theory, a water permit of 1 litre per second for agricultural use is the equivalent to a total volume of $6,307 \mathrm{~m} 3 /$ year. The theoretical use factor was $75 \%$ for drinking water and the mining industry.

Using data from the Water Right Registry (DGA, 2016), we estimated that, theoretically, the total volume used was 239 million m3/year (Table 3). Due to improvements in water use efficiency, the actual use factor is much higher. It is closer to $40 \%$ for agriculture and $100 \%$ for mining and drinking water. Thus, the total volume actually extracted is estimated at 384 million m3/year. This simple calculation 
illustrates that the state significantly underestimated groundwater abstraction when it granted the permits.

This underestimation was later accentuated by the emergence of a WR market. Between 1987 and 2013, the market transactions for water between agriculture on the one hand and the mining and drinking water industries on the other hand, led to an additional 10\% increase in actual WR use. Consequently, total abstraction reached 421 million m3/year. In this way, the market exacerbated a problem that was originally due to an inadequate specification of property rights.

\section{[Insert Table 3]}

\section{Compliance and enforcement problems}

A fourth explanatory factor is the problem of compliance and enforcement GWAs are legally responsible for monitoring use and enforcing compliance with the water extraction limit. Given their failure to fulfil this obligation, the DGA stepped in as a substitute. However, the latter suffered from a lack of human, technical and financial resources (World Bank, 2013). To improve this situation, the Decree 203-2013 (Gobierno de Chile, 2013) stated that all groundwater users were obliged to install measuring equipment and inform the DGA of their water extraction levels (although this provision was already included in the WC81). At present, very few users have installed measuring equipment accredited by the DGA and fewer still inform the DGA of their extraction levels. In April 2016, the DGA started developing an Internet platform so that users could declare their pumping online. In Copiapó, the DGA conducted random checks, although this only led to seven official police reports in a 12year period. The stakeholders that we encountered in the field perceive the cost of non- 
compliance as being lower than compliance, which suggests that the level of fraud is probably quite high. This situation generates a weak social norm: some farmers openly acknowledge that they do not comply with the terms of their water use rights.

\section{Inconsistency between the management of surface water and groundwater}

Last but not least, policies rarely integrate surface and groundwater management and those that do are contradictory. For example, the National Irrigation Commission (CNR) has heavily subsidized the modernization of gravity-fed irrigation systems. The canals were lined, drip irrigation was developed and the savings in water enabled the owners of surface WR to increase their irrigated areas. Moreover, the CNR has made no secret of its goal to improve and increase irrigation. Yet the modernization of irrigation reduces leaks and infiltration, thereby, hindering artificial recharge of the aquifer, which accounts for nearly $60 \%$ of total recharge (Alamos and Peralta 1987). Additionally, given that Aguas Chañar now sells treated water to a large mining plant, their river discharge reduced groundwater recharge by 0.5 million m3 per year (Hidromás CEF limitada, 2013).

\section{The emergence of collective management}

\section{Solving the crisis by imposing collective management}

In the mid-2000s, the DGA finally succeeded in stabilizing the number of WR by declaring these sectors of the aquifer under restriction (DGA Resolution 232-1994; Gobierno de Chile, 1994). In accordance with article 65 of the WC81, the DGA then required users to form GWAs to take responsibility for resolving both issues. Under the Chilean legal system, the users should take the necessary steps to defend their water use 
rights because they are a matter of private property. In the absence of public interest, the state is not allowed to intervene directly to restore the balance (and pay the associated costs); unless one or more WR holders formally petition DGA to intervene. This approach is similar to the management of surface irrigation systems (Rivera, 2015).

Despite the theory, when the basin was classified as a prohibited zone in 1993, the state failed to impose collective management on users. The latter were more concerned by short-term costs than long-term benefits. In 2001, the DGA allowed provisional WR to be granted in sections 5 and 6, on condition that a users' association was set up. This motivated a group of farmers (both large and small) to take the first steps. The Comunidad de Aguas Subterráneas Copiapó - Piedra Colgada; Piedra Colgada - Desembocadura (CASUB) was finally judicially constituted in 2004. In the other sectors of the aquifer, the GWAs were established judicially in 2015.

\subsection{The gradual development of CASUB}

CASUB brings together all the holders of groundwater rights in the downstream area (Sectors 5 and 6). It comprises 204 holders in the agricultural sector, four mining companies and a drinking water company, Aguas Chañar. The users operate 187 boreholes, with a total authorized pumping capacity of 5,500 L/s, of which only 1,000 L/s are actually used.

CASUB only became operational in 2008. However, the lack of clearly defined operational rules has limited its management capabilities. Its rules of operation were recently approved in 2013; however, they are still not fully known by all users. Furthermore, they have not yet been implemented since the DGA has not formally 
registered them, as a result of conflicting administrative views of CASUB's attributions, due to different interpretations of the WC81 (Vergara et al., 2013).

Nonetheless, CASUB has been able to implement some actions to move towards a more effective collective groundwater management. Its first achievement was to clearly delineate its boundaries and identify its members, by establishing a detailed registry of water permits, combined with a geographic information system (GIS) referencing all the boreholes. The information is updated regularly and the contents of the GIS are gradually being augmented. Thus, this GWA has.

In addition, CASUB is developing its capacity to support users (mainly farmers) in administrative procedures for obtaining provisional permits or permission to change extraction points. It also provides support to help users find public funding to deepen wells and modernize irrigation systems. CASUB's director, who has a thorough technical understanding of the aquifer dynamics, advises farmers on solving problems linked to operating their facilities.

The range of services offered has recently been broadened. A website will soon enable users to obtain information on the levels of the water table and their dynamic trends. It will incorporate tools to help manage irrigation at the farm level, such as highresolution aerial photographs, which will allow individual farmers to locate faulty operations in their irrigation systems. The community is financed by a fee that is proportional to the litres per second specified in the WR. The revenues generated by the fees are supplemented by public funds, which may be granted to the association on the basis of its projects.

All these activities that support users help generate a sense of belonging to the community. However, most members have yet to be convinced. The interviews we 
conducted in 2016 suggest that only a small group of members are now fully aware of the community's significance and are actively involved in the association. The majority constitutes both small and large farmers. The former feel excluded (since decisions depend on the number of votes, which are proportional to the discharge on the water permits), while the latter are pursuing a free-rider strategy.

Thus, as Table 4 summarizes, CASUB does not fully satisfy Ostrom's 8 principles for an effective common pool groundwater management, which explains its limited collective management capability.

\section{[Insert Table 4]}

Nonetheless, after 11 years of existence, CASUB's Board of Directors believe that it is sufficiently well organized to take on the thorny issue of reducing groundwater extraction, the principal reason for its creation. This could be achieved by applying a uniform reduction coefficient to all WR. An alternative scenario is emerging. It involves a petition that has been submitted to the DGA to replace the management of discharges by volume management. A reduction in authorized volumes could be accompanied by technical and financial assistance to improve the efficiency of irrigation. The detailed workings of this scenario will be developed though participatory workshops held by CASUB, with support from the authors of this paper.

\section{Discussion and Conclusion}

Initially, Chile's water legislation paid little attention to the sustainable management of groundwater because it represented a marginal water source in the early 80 s. The need to improve the regulation of groundwater management was acknowledged as a result of the increased levels of groundwater pumping. The 2005 amendment of WC81 
introduced procedures to achieve sustainable groundwater resource management. The effectiveness of this policy model depends on the capacity of the state and the water users to impose a Sustainable Abstraction Limit (SAL), share the volume corresponding to the SAL among the various users, enable the reallocation of rights among users, set out the rules with regard to adjusting the volume of the granted rights, implement an effective monitoring and performance strategy and, lastly, revise SAL periodically to account for changes in resource conditions and climate.

In order to improve groundwater management, GWAs have been set up in a few basins, mainly as a result of state coercion. Several years on, a limited number of these associations have started to play an active role in groundwater management. Their main challenge is to mobilize their members and improve dialogue with state agencies. The GWAs were established in a 'weak governance context' (Faysse et al., 2014), where interactions between users and the actors in charge of groundwater resource management (GWA board members and state agencies) were very limited and the (long-term) benefits of cooperation were not fully understood. In order to change this situation and move towards co-management involving the state and users, a mutual understanding of stakeholders' interests, concerns and preferences is required. This calls for dialogue and deliberation. It represents a key challenge in Copiapó in the years to come.

An examination of the Copiapó Valley case has shown that even in a developed country (Chile's per capita income has passed the threshold defined by the World Bank for high-income or developed economies), like Chile, with highly sophisticated water legislation, the state and water user associations were not in a position to apply an effective management model based on the granting of individual permits. 
We have identified the main determinants that explain Copiapó's groundwater depletion. In the first place, the state belatedly closed the groundwater basin, partly due to inconsistent technical information. Understanding groundwater dynamics is one of the key elements when it comes to evaluating the present and long-term abstraction levels. Secondly, legal complexities and political pressure led to the allocation of WR that exceeded the established abstraction limits. Even under a prohibition decree the state continued granting WR in response to an increased number of petitions to regularize customary WR, as well as to pressure from other state agencies and economic sectors.

Poorly defined WR constitute a third factor. WR granted on the basis of theoretical use factors led to increased volumetric water consumption over time, due to the adoption of water conservation technology. The increased water consumption was later accentuated by the existence of WR markets, which meant that WR could be transferred between sectors characterized by different water extraction intensities.

In fourth place, compliance and enforcement problems can explain the groundwater overdraft of legal boreholes, as well as the existence of illegal boreholes. Water user associations are responsible for monitoring and enforcement. However, the existing association did not fulfil its role. In addition, GWA were non-existent in the upper sections of the aquifer. Thus, the state had to take on this responsibility, without the necessary adjustments in budget and personnel.

Lastly, the fifth factor relates to the inconsistency between surface and groundwater management. The lack of conjunctive surface and groundwater management is a major determinant. However, the deficient coordination between sectoral and resource policies has led to contradictory policies. For example, the DGA 
implements policies to achieve sustainable groundwater abstraction, while the CNR subsidizes the adoption of efficient irrigation technologies in order to increase the irrigated area (World Bank, 2013).

It is likely that these factors are also important determinants of groundwater management in other situations (Closas and MOlle, . Therefore, we argue that the overallocation situation is inevitable. In general, the state only conducts studies to quantify the sustainable abstraction limit when the groundwater levels begin to fall. Indeed, diminishing groundwater levels are symptomatic of over-allocation problems and may even indicate illegal withdrawals. We have formulated three main recommendations that should be considered in a new policy.

The first is to establish a precise definition of the authorized uses, in terms of volume. Although management by discharge (inspired by the management of canals) is easy to apply, it is not advisable for groundwater unless it is combined with volumetric management (cf. the difficulties we have described in Copiapó).

The second recommendation is to clearly define the permits in proportion to an overall resource, i.e. the availability (in volume), and to adjust the volume allocated annually for the available resource. This principle is standard for hydraulic works, where user rights are defined in relation to available supply (in a dam, for example). It is essential to introduce this idea to groundwater management. It should be applied as soon as permits are established in order to avoid generating a feeling of individual ownership with regard to a nominal volume or discharge.

The third recommendation is to set up a crisis management mechanism, which can be activated when management based on a system of permits becomes dysfunctional. For example, this means defining piezometric trigger levels. When these 
levels are exceeded, they trigger a restriction or temporary prohibition on use or automatically reduce the authorized volumes the following year. Although the Chilean WC81entitles GWAs to implement mechanisms of this kind, they have never actually been applied because there are no incentives and it is difficult for users to reach a consensus. This raises questions about the role of the state and the tools it should use (coercive versus incentive) when users fail to abide by the existing regulatory framework.

\section{References}

Alamos \& Peralta (1987) Analisis y evaluacion de los recursos hidrogeologicos Valle del Copiapo - III Región [Analysis and evaluation of hydrogeological resources of the Copiapo Valley III Region]. (Report) Dirección General de Aguas, Ministerio de Obras Públicas. Santiago, Chile. Retrieved from http://documentos.dga.cl/REH591v1.pdf

Bauer, C.J. (2004). Results of Chilean water markets: Empirical research since 1990. Water Resources Research, 40, W09S06, doi:10.1029/2003WR002838.

Bitran, E., Rivera, P., \& Villena, M.J. (2014). Water management problems in the Copiapó Basin, Chile: markets, severe scarcity and the regulator Water Policy, 16 (5), 844-863

Budds, J. (2009). Contested H2O: Science, policy and politics in water resources management in Chile. Geoforum, 40 (3), 418-430.

Closas, A. and F Molle (2016) Groundwater governance in the Middle East and North Africa. IWMI Project Report. Colombo: IWMI.

Closas, A., Molle, F., \& Hernández-Mora, N. (2017). Sticks and carrots to manage groundwater over-abstraction in La Mancha, Spain. Agricultural Water Management, 194, 113-124. 
COCHILCO, Comisión Chilena del Cobre. (2013). Estadísticas del Consumo de Agua en la Minería del Cobre año 2013 [Statistics on Water Consumption in Copper Mining 2013]. Ministerio de Minería, Chile. Retrieved from https://www.cochilco.cl/Paginas/Estadisticas/Bases\%20de\%20Datos/Agua.aspx Cristi, O., Melo, O., \& Donoso, G. (2014). Análisis Estimación Del Precio Privado De Los Derechos De Aprovechamiento De Aguas, (Report BIP 30124562-0). Comisión Nacional de Riego, Ministerio de Agricultura de Chile. Santiago, Chile.

De Stefano, L., Fornés, J. M., López-Geta, J. A., \& Villarroya, F. (2015). Groundwater use in Spain: an overview in light of the EU Water Framework Directive. International Journal of Water Resources Development, 31 (4), 640-656.

DGA. (2016). Registro Público de Derechos de Aprovechamientos de Aguas [Public Registry of Water Use Rights]. Dirección General de Aguas, Ministerio de Obras Públicas, Chile. Retrieved from http://www.dga.cl/administracionrecursoshidricos/registro_publico_daa/Paginas/def ault.aspx

Dictuc. (2010). Análisis integrado de gestión en cuenca del Río Copiapó. DGA - MOP Donoso, G. (2015). Chilean Water Rights Markets as a Water Allocation Mechanism. In (Eds) Lago, M., Mysiak, J., Gómez, C.M., Delacámara, G., \& Maziotis, A. Use of economic instruments in water management: insights from international experience. (pp 265-278). Global Issues in Water Policy, vol 14. Springer-Verlag, Switzerland.

Donoso, G., \& Vicuña, S. (2016) Aseguramiento responsable del agua para consumo humano. Unpublished manuscript, Espacio Público, Santiago, Chile

Donoso, G., Melo, O., Jordan, C. (2014a) Estimating Water Rights Demand and Supply: Are Non-market factors important?. Water Resources Management, 28 (12), 4201-4218

Donoso, G., Blanco, E., Vergara, A., Rivera, D. (2014b). Capacitación y apoyo a comunidades de aguas subterráneas en el valle de Copiapó, Región de Atacama [Capacity building and support to groundwater communities in the Copiapó Valley, Atacama Region]. (Report 870-80-LP11). Comisión Nacional de Riego, Ministerio Agricultura. Santiago, Chile.

EC, European Commission. (2000). European Parliament and Council. Directive 2000/60/EC of the European Parliament and of the Council of 23 October 2000 
establishing a framework for Community action in the field of water policy. http://eur-lex.europa.eu/resource.html?uri=cellar:5c835afb-2ec6-4577-bdf8756d3d694eeb.0004.02/DOC_1\&format=PDF

ECONSSA, Empresa Concesionaria de Servicios Sanitarios S.A. (2014). Memoria Anual 2013 [Annual Memory, 201]. Corporación de Fomento de la Producción, CORFO. http://www.econssachile.cl/Memoria_2013/

ECONSSA, Empresa Concesionaria de Servicios Sanitarios S.A. (2015). Memoria Anual 2014 [Annual Memory, 2014]. Corporación de Fomento de la Producción, CORFO. http://www.econssachile.cl/Memoria_2014/

EMG, EMG Consultores S.A. (2011). Estimación del Precio de Mercado y Precio Social de los Derechos de Aprovechamiento de Aguas [Estimate of Market and Social Price of Water Use Rights]. (Report) Subsecretaría de Agricultura, Ministerio de Agricultura. Santiago, Chile.

Faysse, N., Errahj, M., Imache, A., Kemmoun, H., \& Labbaci, T. (2014). Paving the way for social learning when governance is weak: Supporting dialogue between stakeholders to face a groundwater crisis in Morocco. Society \& Natural Resources, 27 (3), 249-264.

Giordano, M., \& Villholth, K.G. (2007). The agricultural groundwater revolution: opportunities and threats to development. Volume 3 of Comprehensive assessment of water management in agriculture series. CABI. Oxfordshire, UK.

Gobierno de Chile. (2013). Decreto 203, Reglamento y Normas de Exploración y Explotación de Aguas Subterráneas [Rules and Regulations for Exploration and Exploitation of Groundwater]. Dirección General de Aguas, Ministerio de Obras Públicas Santiago, Chile. http://www.leychile.cl/Navegar?idNorma=1060095

Gobierno de Chile (1993). Resolución 193: Declara zona de prohibición para nuevas explotaciones de aguas subterráneas en la Cuenca del Río Copiapó, Provincia de Copiapó, III Región [Declares prohibition zone for new groundwater exploitations in the Copiapó River Basin]. Dirección General de Aguas, Ministerio de Obras Públicas. Santiago, Chile. http://www.dga.cl/administracionrecursoshidricos/aprohibicion/Documents/res_193. pdf 
Gobierno de Chile (1994). Resolución 232: Reduce zona de prohibición para nuevas explotaciones de aguas subterráneas en la Cuenca del Río Copiapó, Provincia de Copiapó, III Región, declarada por Resolución DGA N 193, de 27 de mayo de 1993 [Reduces prohibition zone for new groundwater exploitations in the Copiapó River Basin, Copiapó Province, Region III, declared by Resolución DGA № 193, de 27 de mayo de 1993]. Dirección General de Aguas, Ministerio de Obras Públicas., Santiago, Chile. http://www.plataformacaldera.cl/biblioteca/589/articles66307_documento.pdf

Gobierno de Chile. (1981). Decreto con Fuerza de Ley 1122 que fija texto del Codigo

De Aguas [Establishes text of the Water Code.]. Ministerio de Justicia. Santiago,

Chile. https://www.leychile.cl/Navegar?idNorma=5605

Golder Associates. (2006) Diagnóstico de los Recursos Hídricos de la Cuenca del Río Copiapó y Proposición de un modelo de Explotación Sustentable [Diagnosis of Water Resources in the Copiapó River Basin and a Proposal of a Sustainable Exploitation Model]. Copiapó, Chile.

Grafton, R.Q., Horne, J., Wheeler, S. (2016) On the marketisation of water: Evidence from the Murray-Darling Basin Australia. Water Resources Management, 30 (3), 913-926.

Hammer, U. \& Asociados (1980). Plan Maestro de Acción Inmediata para el Desarrollo de los Recursos de Agua y Suelo del Valle de Copiapó [Master action plan for the Development of land and water Resources of the Copiapó Valley]. (Report) Dirección de Riego, Ministerio de Obras Públicas. Santiago, Chile.

Iftekhar, M.S., \& Fogarty, J. (2017). Impact of water allocation strategies to manage groundwater resources in Western Australia: Equity and efficiency considerations. Journal of Hydrology, 548 (May 2017), 145-156.

doi.org/10.1016/j.jhydrol.2017.02.052

INE. (2012). Resultados Preliminares Censo de Población y Vivienda 2012

[Preliminary Results Population and Housing Census 2012]. Instituto Nacional de Estadísticas de Chile, Ministerio de Economía, Fomento, y Turismo. Santiago, Chile. Retrieved from http://www.bcn.cl/obtienearchivo?id=repositorio/10221/15525/1/Censo\%20datos\% 20preliminares\%20fin_v5.doc 
Hidromás CEF limitada. (2013). Actualización de la modelación integrada y subterránea del acuífero de la cuenca del río Copiapó [Update of the integrated and underground modeling of the basin of the Copiapó river basin]. (Informe S.I.T. N ${ }^{\circ}$ 332) Dirección General de Aguas, Ministerio de Obras Públicas. Santiago, Chile. Retrieved from http://documentos.dga.cl/SUB5460v1.pdf

Kuper, M., Faysse, N., Hammani, A., Hartani, T., Marlet, S., Hamamouche, F., Ameur, F. (2016). Liberation or anarchy? The janus nature of groundwater on north africa's new irrigation frontiers. In: Jakeman, A.J., Barreteau, O., Hunt, R.J., Rinaudo, J,D., Ross, A. Integrated Groundwater Management: Concepts, Approaches and Challenges (pp 583-615). Springer International Publishing, Cham. doi.org/10.1007/978-3-319-23576-9_23

Madramootoo, C.A. (2012). Sustainable groundwater use in agriculture. Irrigation and Drainage 61(S1), 26-33.

Mays, L.W. (2013) Groundwater Resources Sustainability: Past, Present, and Future. Water Resources Management 27 (13), 4409-4424

McFarlane, D. \& Norgate, T. (2012). Summary report on Copiapó water yields and demands. Unpublished report to AusAID as part of the study: “Copiapó River Basin, Chile - analysis study of shortfalls in water rights, industrial usage and social requirements' from the Minerals Down Under Flagship, CSIRO. Retieved from https://publications.csiro.au/rpr/download?pid=csiro:EP126400\&dsid=DS4

McFarlane, D. \& Norgate, T. (2012). Summary report on Copiapó water yields and demands. Unpublished report to AusAID as part of the study: "Copiapó River Basin, Chile - analysis study of shortfalls in water rights, industrial usage and social requirements' from the Minerals Down Under Flagship, CSIRO. Retrieved from https://publications.csiro.au/rpr/download?pid=csiro:EP126400\&dsid=DS4

McKay, J. (2012). Groundwater management: looking to the future so there is a future. Water International 37 (7),721-726 doi:10.1080/02508060.2012.741038

Minera Luminar Copper Chile. (2008). Informe consolidado de la evaluación del estudio de impacto ambiental del proyecto "proyecto caserones" [Consolidated report of the environmental impact study of the "Caserones project"]. Sistema de Evaluación de Impacto Ambiental, Ministerio de Medio Ambiente. Santiago, Chile. Retrieved from 
http://infofirma.sea.gob.cl/DocumentosSEA/MostrarDocumento?docId=bf/48/8acf0 $\underline{1 \mathrm{~d} 3 \mathrm{~b} 400 \mathrm{a} 0712 \mathrm{e} 7534538619 \mathrm{cebebf58}}$

Nevill, C.J. (2009). Managing Cummulative Impacts: Groundwater Reform in the

Murray-Darling Basin, Australia. Water Resources Management 23 (13), 2605-2631

Oyarzún, R., Arumí, J. L., Alvarez, P., \& Rivera, D. (2008). Water use in the Chilean

agriculture: current situation and areas for research development. In (Ed.) Sørensen,

M.L. Agricultural Water Management Research Trends (pp 213-236). Nova

Publishers. New York, USA.

Partarrieu, U., Parra, A., Peña C., Ferrada, F.K., Sepúlveda, A.V, Valenzuela, D.P.,

Vergara, S. (2009). Plan de Gestión para la Cuenca del Copiapó [Management Plan for the Copiapó Basin] (Report ADM 5374). Secretaría CONAMA and

DGA.Santiago, Chile. http://documentos.dga.cl/ADM5374.pdf

Petit, O., Kuper, M., Lopez-Gunn, E., Rinaudo, J-D., Daoudi, A., Lejars, C. (2017) Can Agricultural Groundwater Economies collapse? An Inquiry into the Pathways of four Groundwater Economies Under Threat. Hydrogeology Journal (25) (6), 15491564

Red Agrícola (2016) La Batalla del Agua de Copiapó. Retrieved from http://www.redagricola.com/reportajes/agua/la-batalla-del-agua-de-copiapo

Rinaudo, J-D., Moreau, C., Garin, P. (2016). Social Justice and Groundwater Allocation in Agriculture: A French Case Study. In (Eds.) Jakeman, A.J., Barreteau, O., Hunt, R.J., Rinaudo, J,D., Ross, A. Integrated Groundwater Management: Concepts, Approaches and Challenges (pp 273-293). Springer International Publishing, Cham, 10.1007/978-3-319-23576-9_11

Rivera, D. (2015). Diagnóstico jurídico de las aguas subterráneas [Legal analysis of groundwater]. Ius et Praxis, 21 (2), 225-266

Saak, A.E., \& Peterson, J.M. (2007). Groundwater use under incomplete information. Journal of Environmental Economics and Management, 54 (2), 214-228

Sernageomin. 2017. Estadísticas de Concesiones Mineras [Mining Concession Statistics]. Ministerio de Mineria, Chile. http://www.sernageomin.cl/smineraestadisticasconc.php

Scanlon, B.R., Faunt, C.C., Longuevergne, L., Reedy, R.C., Alley, W.M., McGuire, V.L., \& McMahon, P.B. (2012). Groundwater depletion and sustainability of 
irrigation in the US High Plains and Central Valley. In W.A. Jury (Ed.) Proceedings of the National Academy of Sciences (pp. 9320-9325). Washington D.C., USA.

Scott, C.A., Shah, T. (2004). Groundwater overdraft reduction through agricultural energy policy: insights from India and Mexico. International Journal of Water Resources Development 20 (2),149-164.

Shah, T. (2005). Groundwater and human development: challenges and opportunities in livelihoods and environment. Water Science and Technology 51 (8), 27-37

Troncoso, R., Espinoza, C.M., Pérez, D., Castro, M., Lorca, V., Vega, N. ... Wall, Z. (2012). Evaluación hidrogeológica de la cuenca del río Copiapó, con énfasis en cuantificación, dinámica y calidad química de los recursos hídricos superficiales y subterráneos [Hydrogeological evaluation of the Copiapó river basin, with emphasis on quantification, dynamics and chemical quality of surface and groundwater resources]. (Informe Registrado IR-12-49), Sernageomin, Ministerio de Mineria. Santiago, Chile. Retrieved from http://biblioteca.sernageomin.cl/opac/index.asp?param=0\%AD\%88\%92bl\%99\%8C $\mathrm{q} \% 5 \mathrm{E} \& \mathrm{Op}=3$

Vergara, A. (1992). Contribución a la historia del derecho de aguas, III: Fuentes y principios del derecho de aguas indiano [Contribution to the history of water law, III: Sources and principles of water law]. Revista Chilena de derecho 19 (2),311332

Vergara, A., Rivera, D., Moyano, V., Donoso, G., \& Blanco, E. (2013). Aguas y Energía: Propuestas para su autogobierno y resolución especializada de conflictos [Water and Energy: Proposals for self-government and specialized conflicto resolution]. In I. Irrarazabal, E. Piña, \& M. Letelier (Eds.). Concurso de Políticas Públicas 2016: Propuestas para Chile (pp. 241-270). Pontificia Universidad Católica de Chile. Centro de Políticas Públicas.

Vergara, A., Arévalo, G., Muñoz, G., Rivera, D., \& Vergara, C. (2011). Codigo de Aguas Comentado [Commented Water Code]. Abeledo Perrot Legal Publishing Chile, Santiago, Chile

Wada, Y., van Beek, L,P,H, van Kempen, C.M., Reckman, J.W.T.M., Vasak S, Bierkens M.F.P. (2010). Global depletion of groundwater resources. Geophys. Res. Lett., 37, L20402, doi:10.1029/2010GL044571 
Watto, M.A., \& Mugera, A.W. (2016). Groundwater depletion in the Indus Plains of Pakistan: imperatives, repercussions and management issues. International Journal of River Basin Management, 14 (4), 447-458.

World Bank (2013) Estudio para el mejoramiento del marco institucional para la gestión del agua [Water institutional framework improvement study]. Dirección General de Aguas, Ministerio de Obras Públicas de Chile. Retrieved from http://reformacodigodeaguas.carey.cl/wp-content/uploads/2014/09/Informe-BancoMundial-Estudio-para-el-mejoramiento-del-marco-institucional.pdf. 
Table 1. Table 1: Aguas Cañar's Operating Wells $\left(\mathrm{N}^{\circ}\right)$ and Average Extraction Flows $(\mathrm{L} / \mathrm{s})$

Table 2. Estimated replacement cost of dry wells in Sectors 5 and 6 in the Copiapó Valley.

Table 3. Theoretical and actual use factors and corresponding volumes used.

Table 4. Evaluation of CASUB's degree of satisfaction of Ostrom's 8 Principles

Figure 1. Location of the Copiapó Valley and division of the alluvial aquifer into hydrogeological management sectors.

Figure 2. Longitudinal section of the aquifer showing the various sectors (adapted from Hidromás CEF limitada 2013).

Figure 3. Change in the total volume stored in the Copiapó aquifer between 1974 and 2007 (adapted from Hidromás CEF limitada 2013)

Figure 4. Modelled changes in aquifer volume between La Puerta and Angostura after 2012 (adapted from McFarlane and Norgate 2012)Figure 5. Evolution of total extraction flows for drinking water supply (adapted from Hidromás CEF limitada 2013)

Figure 6. History of the granting of groundwater permits in the Copiapó Valley (adapted from Donoso et al. 2014b) 